\title{
Investigation of Solution Focused-Brief Counseling's effect on reducing the stress levels of college students
}

\author{
Franciskus Rondang Sitindaon ${ }^{1}$, Rahma Widyana $^{2^{*}}$ \\ ${ }^{12}$ Universitas Mercu Buana Yogyakarta
}

\section{Article Info \\ Article history: \\ Received Jul 08th, 2020 \\ Revised Aug 02nd, 2020 \\ Accepted Aug 10th, 2020}

\section{Keyword:}

Solution focused-brief counseling

Stress level

College students

\begin{abstract}
College students deal with various events that can increase stress levels and negatively impact their lives. The study aimed to investigate the effect of solution-focused brief counseling (SFBC) on reducing college students' stress levels. The hypothesis suggested a decrease after comparing the stress level with SFBC before the intervention. The Participants consisted of 6 active postgraduate psychology students with moderate and high-stress levels. Furthermore, the study used a one-group pretest-posttest design, and the data were obtained through the Stress Scale for College Students (SSCS) and interview. The intervention used SFBC, and was conducted in four meetings. In analyzing the data, the Wilcoxon Signed Ranks Test was used to determine the difference in experimental group values between before and after the intervention. The result showed that there are differences in stress levels before and after the procedure, and its drastic decrease in participants was observed after the intervention.
\end{abstract}

Corresponding Author:

Rahma Widyana

Universitas Mercu Buana Yogyakarta

Email: rahma@mercubuana-yogya.ac.id

\section{Introduction}

Stress is a common condition that affects people irrespective of age and education level (Aiken, 2002; Sarafino \& Smith, 2011). It is an individual internal and external response that affects the physiological, psychological, cognitive, and behavioral aspects (Scott, 2008). College students tend to discover different options related to academic (paperwork or exams) and non-academic opportunities, such as interpersonal relationships or adjusting to a new environment which can be a source of stress (Nurhidayati, 2011; Triaswari, 2014). College students with the ability of adapting to this development at young age are expected to have the skills to handle and manage stress (Kail\& Cavanaugh, 2010). In contrast, some of the students under prolonged stress showed a negative impact on physical, cognition, emotion, and social behavior.

The study by Bukhsh, Shahzad, and Nisa (2011) reported a negative impact of stress using 200 college students. In addition, it showed that stress causes disturbance in physiological (muscle tension, changes in appetite, headache), cognitive (attention and memory problem), psychosocial (anxiety and angry easily). Bukhsh, Shahzad, \& Nisa (2011) added that when students are under continuous stress condition, their concentration and attention will be compromised and they will not enjoy learning because of frustration and the feeling of being anxious, antisocial and aggressive behavior. From the studies on medical students' internships, some failed to manage stress until they suffered burnout, and they negatively impacted health progression, work performance, and health care quality (Lue, Chen, Wang, Cheng, \& Chen, 2010). O'Connell (2001) reported that a person with a persistent stress condition usually has the ability to manage it. However, when under stress situations, the ability to obtain a solution is highly reduced. Therefore, the interventions to address the situation of helping students manage stress is known as solution focused-brief counseling (SFBC). 
Early application of SFBC mostly in a clinical setting and further development of psychology service, and techniques can also be applied in an educational setting (Schmit, Schmit, \& Lenz, 2016; Kim \& Franklin, 2009; Kim, Kelly, \& Franklin, 2017). Kim et al. (2017) explained that SFBC helps to increase mental health in an educational background. This claim is supported by a growing case in school and requires short-term work to make major changes through an academic system that focuses on small changes (Adigüzel \& Göktürk, 2013; Kim \& Franklin, 2009; Kim et al., 2017).

Pratiwi and Nuryono (2014) showed that the application of SFBC in high school students grade IX helps to increase their self-esteem. The result showed that SFBC influences the academic status of students by increasing their self-esteem. Two studies that have adopted its application are in junior high school students (Eka, Bashori \& Hayati, 2014) and study to increase math task accomplishment in six elementary students grade 5 with SFBC (Fearrington, McCallum, \& Skinner, 2011).

It helps stressed people to maximize strengths and abilities as well as to remember old strategies or methods. This means that college students focus more on the problems of stressful situations to persist and have long-term negative effects Also, client-counselor dialogue during counseling helps to identify exceptions, goals, and resources, including positive characters which are focused on the problem behind the client's shadow (Newsome, 2005; O'Connell, 2001).

SFBC application in school background has been used recently with various issues, such as behavior and emotional as well as academic problems, social skills, and school withdrawal prevention programs (Daki \& Savage, 2010; Kim \& Franklin, 2009; Newsome, 2004). Kok-Mung, Parikh, and Guo (2012) reported a single college student participant that had a problem with intimacy. The problems as a stressor were negative emotions, which created social and academic problems for the participants. Furthermore, it was stated that SFBC can have a positive self-perception which helps the student to solve the problem and stimulate positive strategies in managing negative emotions.

Rusandi and Rachman (2014) examined the effectiveness of SFBC in increasing college self-esteem, and they obtained a phenomenon in some college students that failed facing academic tasks, such as thesis proposal rejected by lectures. The student felt disappointed, low enthusiasm to complete the thesis, pessimism, low confidence to revise, and unable to accept the failure. The result showed that SFBC increases students' positive self-esteem to feel optimistic about various academic tasks, manage problems, and finish the study. It was supported by the statement that high self-esteem can negate stress levels (Aboalshamat, Jawhari, Alotibi, Alzahrani, Al-Mohimeed, Alzahrani, \&Rashedi, 2017; Hubbs, Doyle, Bowden, \& Doyle 2012).

Even though many research obtained positive results of SFBC, critics and evaluations about its effects still range from low to moderate. A meta-analysis study by Kim (2008) reported small and positive effects of SFBC application for external (social skills, aggressiveness, truancy, and hyperactivity) and internal behavior (depression, self-concept, and anxiety), as well as family relations problems. Similarly, Kim, Smock, Trepper, McCollum, and Franklin (2010) also obtained the same results on SFBC. Therefore, this present student is focused on increasing the effectiveness of SFBC in the academic setting.

\section{Method}

The participants consist of six active postgraduate students of psychology from University Mercu Buana of Yogyakarta with moderate and high-stress levels. The participants' age is between 20 to 45 years. Furthermore, they were screened using Stress Scale for College Students (SSCS) designed by Kholidah (2009) after a pre-test was conducted. The screening tool assessed four aspects of the physiology, cognitive, emotional, and social behavior of participants. The SSCS options consist of four responses: "Strongly Agree", "Agree", "Disagree" and "Strongly Disagree". The strategy of data collection method before and after the intervention composed of 20 items. The research evaluated SSCS of 144 postgraduate students, and the results showed that twenty-seven items failed and twenty satisfying reliability and index discrimination from 0.266 to 0,510 . Alpha Cronbach from 20 items is 0.812 , and it has a high coefficient reliability greater than 0.7 (Murp \& Davidshore, 1994).

The intervention was conducted in four sessions and each meeting lasted for a maximum of 120 minutes. This research gives 7 days for the second to the third meeting and this was similarly applied to the third and fourth meetings. The aims were to give the 7 days between the second and third meetings the opportunity to train the participant in the practice of the already planned steps, to be repeated with positive consequences and to give the participant a chance to achieve results, and minimize client dependency (Brasher, 2009; 
Young \&Holdrof, 2003). The Intervention utilized is solution focused-brief counseling (SFBC), and its module was based on the book about the application of SFBC by O'Connel (2001), Lutz (2014), and Guterman (2013). The Intervention was led by one counselor (masters of psychology degree) and two observers, and in each session, the participants exploited the worksheets.

In the first session, participants had SSCS in the pretest phase, a declaration of consent form, and two worksheets ('Kekuatanku' and 'Harapanku'). In addition, the second session consists of conscious positive changes related to the participant's goals. The changes related to the four aspects, assessed in SSCS are physiological, cognitive, emotional, and social behavior. In the second session, the counselor encourages the client to obtain strategies that have been used and create a list for a new strategy to help the client achieve their goals. In the third session, the counselor facilitated the client to search for positive change related to the goal by using the scaling technique. In the fourth session, the counselor and client recognize positive changes related to the participant's goal and termination. In every final session, the counselor consistently concludes, compliments the participant for their positive behaviors shown during the process, and asks them to perform positive strategies related to the goals.

Quantitative analysis using the Wilcoxon Signed Ranks Test technique to assess decreasing participant's stress level before and after the intervention was derived from the worksheet and interview in the follow-up session. Therefore, the purpose was to obtain the psychological process of SFBC to four aspects of stress (physiology, cognitive, emotional, and social behavior). The design of the study is a one-group pretestposttest (Creswell, 2009). Therefore, the participant's stress level was measured before and after treatment.

\section{Results and Discussion}

Table 1 showed score data from Stress Scale for College Students (SSCS) before (pre-test) and after the intervention (post-test).

Table 1. Score data pre-test and post-test

\begin{tabular}{cccccc}
\hline No. & Participant & Pre-test & Category & Post-test & Category \\
\hline 1 & $\mathrm{Na}$ & 58 & Normal & 51 & Normal \\
2 & $\mathrm{Da}$ & 56 & Normal & 51 & Normal \\
3 & $\mathrm{Si}$ & 63 & High & 48 & Normal \\
4 & $\mathrm{Ni}$ & 56 & Normal & 47 & Normal \\
5 & $\mathrm{Yu}$ & 53 & Hormal & 44 & Normal \\
6 & $\mathrm{Ri}$ & 62 & & 55 & \\
& & 58 & & 49,33 & \\
\end{tabular}

The hypothesis showed the participant's stress level after SFBC decreases in comparison to its level before the intervention The result from the Wilcoxon Signed Ranks Test showed that Z scores coefficient $=-2.214$ with significance difference $=0.027(p<0.05)$. Furthermore, it showed that there are differences in stress levels before and after the intervention. The mean score before and after the intervention was 58 and 49.33 respectively, and the average difference was 8,67 . Therefore, the stress level of participants was decreased after the intervention.

Generally, the qualitative analysis reported that there are positive changes in physiology, cognitive, emotional, and social behavior which affect the reduction of participant's stress level. One example is that the participant's goal of healing tumors begin to develop, change the perspective of illness as a gift from God, focus on accomplishing, and reducing academic tasks to fix their problems. The result of the qualitative analysis was consistent with previous studies, which reported that self-confidence and optimism are the protective factors against stress (Kaur \& Amin, 2017; Keverski et al., 2016).

The counseling process helps to decrease the participant's stress level starting with the awareness and recognition of a self-capability that can be recognized as character and achievements. Identification of positive power or capability increases the confidence, motivation, and awareness about self-capability. Previous research showed that self-efficacy and optimism had a negative correlation with stress (Kaur \& Amin, 2017; Keverski et al., 2016). In the next phase, participants identify and choose the stressor that resulted in physiological, emotional, cognitive, and social behavior for the last 6 months. The stressor of participants includes the idea to attain many targets, the emotional aspect that creates the feeling of rush in 
completing academic tasks, tumor illness affecting their attention, negative emotion toward a family member, and fatigue feeling with daily activities.

Participants with stressors will move to the next step which is hope for the future. Primarily, the aim is to assist participants in achieving their goal and it provides positive effects. O'Connell (2001) reported that the collaboration between the participant and the counselor in creating small steps can be applied by their confidence. The participant helps the participants to investigate before choosing a good strategy of reaching the desired goal. The small step created help in goals' achievement and provides a feeling of calmness and clear direction.

The next phase is related to the positive power of the participant to create good actions in achieving their goal. This awareness influences the process of recalling past accomplishments and methods of achieving them. The steps provided the participant with clear instructions on how to achieve their dream and ensure increasing optimism, self-confidence, and coping strategies. They also stated that remembering the old and the new strategy gives the confidence to address the problem. This result is consistent with previous research conducted by Kok-Mung, Parikh, and Guo (2012), and it showed that SFBC increases the self-positive perception that helps the student to accept their problem and create a positive strategy to deal with negative emotions.

In the next step, the counselor and client conducted the counseling process review for the previous session, and it included positive changes associated related to the goal of counseling. This phase provided a positive influence on the participants. Furthermore, they identify the positive methods or strategies which was used to help participants in identifying new methods to increase the positive changes in their lives. From a cognitive point of view, positive changes that increase confidence in the implementation of a strategy or method, such as good time management or focusing on the goal, gradually identify the participants. In an emotional aspect, they tend to feel motivated, calm, and comfortable with themselves. And for the behavior aspect, they recall the positive strategies which are applied for the same problem.

The identification of past achievements and the successful methods increases positive behavior in the face of problems and changes that have already occurred, and this helps to improve the client's confidence and optimism. The previous result explained that self-efficacy, optimism, or resiliency have a negative correlation in stress (Kaur \& Amin, 2017; Kevereski et al., 2016), and this means a low-stress due to the high level of confidence. Furthermore, Rusandi and Rachman showed that the application of SFBC can increase the positive self-esteem of university students as they become optimistic about performing various academic tasks, solving problems, and completing their studies. The obtained results supported the perspective that a high level of self-esteem decreases stress levels (Aboalshamat, Jawhari, Alotibi, Alzahrani, Al-Mohimeed, Alzahrani, \&Rashedi, 2017; Hubbs, Doyle, Bowden, \& Doyle 2012).

However, the current study has some limitations, first, it involved 6 participants, which affected the result, even when interpreted cautiously. The second limitation is that the research process did not follow the planned schedule. The ideal process is the intervention for all participants conducted in one group and at the same time. In reality, the counseling groups were divided into 3 different duration. Each group consisted of 2 participants, and they were given a different condition along the counseling process.

\section{Conclusion}

The Solution focused-brief counseling (SFBC) decreased stress levels of the participants, and its positive influence affects physiological, emotional, cognitive, and social behavior assessed in SSCS. The appearance of each stress influences each other, and similarly, SFBC helps to reduce stress by identifying skills, problems, creating goals or hopes, and identifying positive changes in physiological, emotional, cognitive, and social behavior goals. The participants also make positive strategies that have been implemented before or create a new strategy to reach the goals. Also, they recalled some successful strategies, modified and applied them to suit different needs or situation. The recalled process provided optimism, confidence, and calmness, which allowed participants to achieve desired goals. Considering the results, it has been suggested that more participants should be involved in the future studies. Also, the intervention procedure should be conducted at the same time under the same treatment conditions. 


\section{References}

Aboalshamat, K., Jawhari, A., Alotibi, S., Alzahrani, K., Al-Mohimeed, H., Alzahrani, M., et al. (2017). Relationship of self-esteem with depression, anxiety, and stress among dental and medical students in Jeddah, Saudi Arabia. Journal of International Medicine and Dentistry, 4(2), 61-68

Adigüzel, Î. B. \& Göktürk, M. (2013). Using the solution focused approach in school counselling. ProcediaSocial and Behavioral Sciences, 106, 3278-3284

Aiken, L. R. (2002). Human development in adulthood. New York: Kluwer Academic Publishers

Brasher, K. L. (2009). Solution-focused brief therapy: overview and implication for school counselors. The Alabama Counseling Association Journal, 34 (2), 20-30

Bukhsh, Q., Shahzad, A., \&Nisa, M. (2011). A study of learning stress and stress management strategies of the students of postgraduate level: a case study of Islamia University of Bahawalpur, Pakistan. Social and Behavioral Sciences, 30, 182-186. doi: 10.1016/j.sbspro.2011.10.036

Creswell, J. W. (2009). Research design: quantitative, qualitative, and mixed methods approaches (Edisi 3). USA: SAGE Publication, Inc.

Daki, J. \& Savage, R. S. (2010). Solution-focused brief therapy: impacts on academic and emotional difficulties. The Journal of Educational Research, 103, 309-326. DOI: 10.1080/00220670903383127

Eka, D. A., Bashori, K. \& Hayati, E. N. (2014). Konseling singkat berfokus solusi untuk meningkatkan orientasi masa depan bidang pendidikan pada remaja SMP 4 Pandak, Bantul, Yogyakarta. Tesis. (tidak diterbitkan). Yogyakarta: Universitas Ahmad Dahlan

Fearrington, J. Y., McCallum, R. S., \& Skinner, C. H. (2011). Increasing math assignment completion using solution-focused brief counseling. Education and Treatment of Children, 34(1), 61-80

Guterman, J. T. (2013). Mastering the art of solution-focused counseling (Edisi 2). USA: American Counseling Association

Hubbs, A., Doyle, E. I., Bowden, R. G., \& Doyle, R. D. (2012). Relationship among self-esteem, stress, and physical activity in college students. Psychological Reports, 110(2), 469-474

Kail, R. V. \& Cavanaugh, J. C. (2010). Human development: a life-span view (Edisi 5). Canada: Wadsworth. Cengage Learning

Kaur, J. \& Amin, S. (2017). Psychological capital and stress among school students. Indian Journal of Positive Psychology, 8(4), 495-499

Kevereski, L., Dimovska, M. K., \&Ristevski, D. (2016). The influence of the emotional inteligence in protection of the mental health in conditions of psychosocial stress. International Journal of Cognitive Research in Science, Engineering and Education, 4(1), 17-21

Kim, J. S., Kelly, M. S., \& Franklin, C. (2017). Solution-focused brief therapy in schools: a 360-degree view of the research and practice principles (Edisi 2). New York: Oxford University Press

Kim, J. S. \& Franklin, C. (2009). Solution-focused brief therapy in schools: a review of the outcome literature. Children and Youth Services Review, 31, 464-470. DOI: 10.1016/j.childyouth.2008.10.002

Kholidah, E. N. (2009). Efektivitas pelatihan berpikir positif untuk menurunkan tingkat stres pada mahasiswa. Tesis. (tidakditerbitkan). Yogyakarta: Universitas Gadjah Mada.

Kok-Mung Ng., Parikh, S., \& Guo, L. (2012). Integrative solution-focused therapy with a chinese female collage student dealing with relationship loss. Int J Adv Counseling, 34, 211-230. DOI: 10.1007/s10447012-9152-x

Lue, B-H., Chen, H-J., Wang, C-W., Cheng, Y., \& Chen, M-C. (2010). Stress, personal characteristics and burnout among first postgraduate year residents: a nationwide study Taiwan. Medical teacher, 32, 400407. DOI: $10.3109 / 01421590903437188$

Lutz, A. B. (2014). Learning solution-focused therapy: an illustrated guide. USA: American Psychiatric Publishing

Newsome, W. S. (2005). The impact of solution-focused brief therapy with at-risk junior high school students. Child \& Schools, 27(2), 83-90

Newsome, W. S. (2004). Solution-focused brief therapy groupwork with at-risk junior high school students: enhancing the bottom line. Research on Social Work Practice, 14(5), 336-343

Nurhidayati, T. (2011). Keefektifan pelatihan mentoring terhadap persepsi mahasiswa tentang peran pembimbing akademik dan tingkat distres pada mahasiswa profesi ners universitas muhammadiyah semarang. Tesis. (tidak diterbitkan). Yogyakarta: Universitas Gadjah Mada

O'Connell, B. (2001). Solution-focused stress counselling. London: SAGE Publication

Pratiwi, M. A. \& Nuryono, W. (2014). penerapan solution focused brief therapy (SFBT) untuk meningkatkan harga diri siswa kelas XI Bahasa SMA A1-Islam Krian. Jurnal BK, 04(03), 1-7 
Rusandi, M. A \& Rachman, A. (2014). Efektivitas konseling singkat berfokus solusi (Focused Brief Therapy) untuk meningkatkan self-esteem mahasiswa program bimbingan konseling FKIP Unlam Banjarmasin. Al 'Ulum, 62(4), 22-28

Sarafino, E. P \& Smith, T. W. (2011). Health psychology: biopsychosocial interaction (Edisi 7). John Wiley \& Sons, Inc

Schmit, E. L., Schmit, M. K., \& Lenz, A. S. (2016). Meta-analysis of solution-focused brief therapy for treating symptoms of internalizing disorders. Counseling Outcome Research and Evaluation, 7(1), 21-39

Scott, C. J. (2008). Optimal stress: living in your best stress zone. New Jersey: John Wiley \& Sons

Triaswari, P. (2014). Kesejahteraan psikologis mahasiswa ditinjau dari stres. Skripsi. (tidak diterbitkan). Yogyakarta: Universitas Gadjah Mada

Young, S. \& Holdorf, G. (2003). Using solution focused brief therapy in individual referrals for bullying. Educational Psychology in Practice, 19 (4), 271-282 